\title{
DER EFFECT DES FOETUS AUF DIE MILCHLEISTUNG DER BETREFFENDEN LAKTATION
}

\author{
T. AURAN, E. FIMLAND, H. SKJERVOLD \\ Landwirtschaftinstitut, As-NLH, Norwegen
}

Es ist beschrieben worden, dass die Hormonaktivitetät der foetalen Plazenta die Euterentwicklung während der Trächtighkeit stimuliert, und dass diese Stimulierung sich auch auf die Milchleistung nach dem Abkalben auswirkt.

Bei der vorliegenden Untersuchung wird die Hypothese getestet, dass der Vater des Foetus auch auf die Milchleistung der betreffenden Laktation influiert.

Etwa 69.000 Kühe mit einer vollständigen Laktationsperiode, wo die monatliche Milchleistung für verschiede Unwelteinflüsse korrigiert wurde, sind bei dem Studium des aVater des Foetus-Effekts " benutzt worden. Dieser Effekt wurde als die Korrelation zwichen dem Phänotyp der Milchleistung der Mutter und dem Genotype des Vater des Foetus estimiert $\left(r_{\mathrm{G}_{f} \mathrm{P}_{d}}\right)$.

Ein signifikanter Fffekt des Vaters des Foetus auf die Milchleistung im letzten Teil der betreffenden Laktation wurde gefunden. I $3^{\circ}$ bis io Tage vor dem Abkalben variert der $\gamma_{G_{f} P_{d}}$ zwischen 0.02 und 0.10 , mit einen Maximalwert 7o-6o Tage vor dem Alskalben.

\author{
BefF BreEd Bulds versus Selected Dual Purpose Bulls for Meat Production \\ N. KÜNZI (*), C. GAILLARD $\left(^{* *}\right)$, H. LEDENBERGER $\left(^{*}\right)$, \\ M. SCHNEEBERGER and F. WEBER \\ (*) Swiss Federal Institute of Technology, Zurich, $Z H$ \\ (**) Swiss AI Association, Zollikofen, BE
}

The mating of small beef type bulls (Angus, Evinger) to reduce difficulties at first calvings is increasingly applied in Switzerland. In contract to this calf producers refuse to use large type beef bulls on their cows because of direct and indirect damages due to increased calving problems. It proved to be an attractive alternative to use specially selected dual purpose bulls tested for ease of calving and high growth rate but low dairy performance, so called M-bulls (Meat bulls), out of the regular AI testing program for Braunvieh and Simmentals.

From I974 to 1976 Charolais, Limousin and Piemontese bulls were included in the AI testing program and compared with Braunvieh-and Simmental B-bulls. Data included progeny from 47 bulls, 7,936 calvings, I, I37 animals with carcass gains and r 30 dissected carcasses. If calving performance and net gains are considered, the M-bulls compete well with the foreign breeds, including the amount of meat in the carcass shows superiority for Charolais and Piemontese crosses. The problem is one of distributing gaines and losses among calf producers, feeders and butchers. It needs specially tested bulls with emphasis on ease of calving out of the specialized beef breeds or sire lines to get the dairy farmer crossing his cows.

\section{GENETIC CORRELATION OF MILK PRODUCTION IN BRITAIN AND IREIAND \\ F. P. CUNNINGHAM and 'T. M. O'BYRNE \\ The Agricultural Institute, Dunsinea, Castleknock, Co. Dublin, Ireland}

Progeny test data on I 35 Friesian bulls tested in Ireland and on their 85 sires tested in Britain were used to estimate the genetic correlations between production in the two countries. Estimated correlations were 0.62 for milk yield, 0.46 for butterfat $p$. I oo and 0.43 for butterfat yield. The results appear to be consistent with reports from other populations. 